\title{
EVOLUTIONARY SIGNIFICANCE OF THE LOSS OF THE CHLOROPLAST-DNA INVERTED REPEAT IN THE LEGUMINOSAE SUBFAMILY PAPILIONOIDEAE
}

\author{
Matt Lavin, ${ }^{1}$ JefF J. Doyle, \\ L. H. Bailey Hortorium, Cornell University, Ithaca, NY 14853 \\ AND \\ JEFFREY D. PALMER ${ }^{2}$ \\ Department of Biology, University of Michigan, Ann Arbor, MI 48109
}

\begin{abstract}
The distribution of a rare chloroplast-DNA structural mutation, the loss of a large inverted repeat, has been determined for 95 species representing 77 genera and 25 of the 31 tribes in the legume subfamily Papilionoideae. This mutation, which is regarded as a derived feature of singular origin within the subfamily, marks a group comprising six temperate tribes, the Galegeae, Hedysareae, Carmichaelieae, Vicieae, Cicereae, and Trifolieae, an assemblage traditionally considered to be monophyletic. This mutation also occurs in the chloroplast genome of Wisteria, a member of the tropical tribe Millettieae whose other members so far surveyed lack the mutation. These new DNA data, together with traditional evidence, support the hypothesis that Wisteria is an unspecialized member of a lineage that gave rise to the temperate tribes marked by the chloroplast-DNA mutation; the probable paraphylesis of Millettieae is revealed. Two other tribes, Loteae and Coronilleae (traditionally regarded as a derived element of the aforesaid temperate tribes) do not possess this chloroplast-DNA structural mutation and, therefore, presumably represent a distinct temperate lineage. This hypothesis is supported by additional evidence from pollen, inflorescence, and root-nodule morphology that suggests that the Loteae and Coronilleae share a more recent ancestry with tropical tribes such as Phaseoleae and Millettieae than with other temperate tribes.
\end{abstract}

Received January 13, 1989. Accepted November 17, 1989

The Leguminosae (or Fabaceae), with approximately 18,000 species and 650 genera, is the third largest plant family, after the Compositae and Orchidaceae. Its taxonomic relationships with other angiosperm plant families are obscure and, consequently, the family is the sole member of the order Fabales (Cronquist, 1981). It is divided into three subfamilies, Caesalpinioideae, Mimosoideae, and Papilionoideae (Polhill and Raven, 1981); of these, Papilionoideae is the largest (with approximately 12,000 species and 440 genera) and economically the most important. Peanuts, beans, peas, sesban, guar, tragacanth, rosewood, indigo, and black locust are examples of economically important papilionoids which provide food, fiber, oils, gums, hardwoods, dyes, and ornamentals. Species of Papilionoideae predominate in nearly every vegetation type throughout the world, from tropical rain forests to deserts, and nearly all species rootnodulate and fix atmospheric nitrogen.

\footnotetext{
${ }^{1}$ Present address: Department of Biology, Montana State University, Bozeman, MT 59717.

${ }^{2}$ Present address: Department of Biology, Indiana University, Bloomington, IN 47405.
}

The higher-level systematics of the Papilionoideae, particularly tribal circumscriptions and interrelationships, has been the subject of much recent study (e.g., Polhill and Raven, 1981; Stirton, 1987). Evidence presented in these investigations of chromosome numbers, seed chemistry, anatomy, pollen morphology, and phytogeography has provided a greater insight into the evolutionary patterns in Papilionoideae and has resulted in a restructuring and rearrangement of many tribes originally circumscribed by Bentham (1865) in his taxonomic system of Papilionoideae. However, many characters used at the higher systematic levels, such as the degree of staminal fusion or legume dehiscence, show a high degree of homoplasy, and evaluation of such characters affects not only tribal relationships, but sometimes tribal circumscriptions as well. As stated by Polhill (1981a), much still remains ill-defined in the subfamily.

Recent work by Palmer and coworkers (summarized in Palmer et al. [1987] and Palmer et al. [1988b]) has shown that the chloroplast genome of diverse Leguminosae possess several major structural mutations, including large inversions and a major dele- 


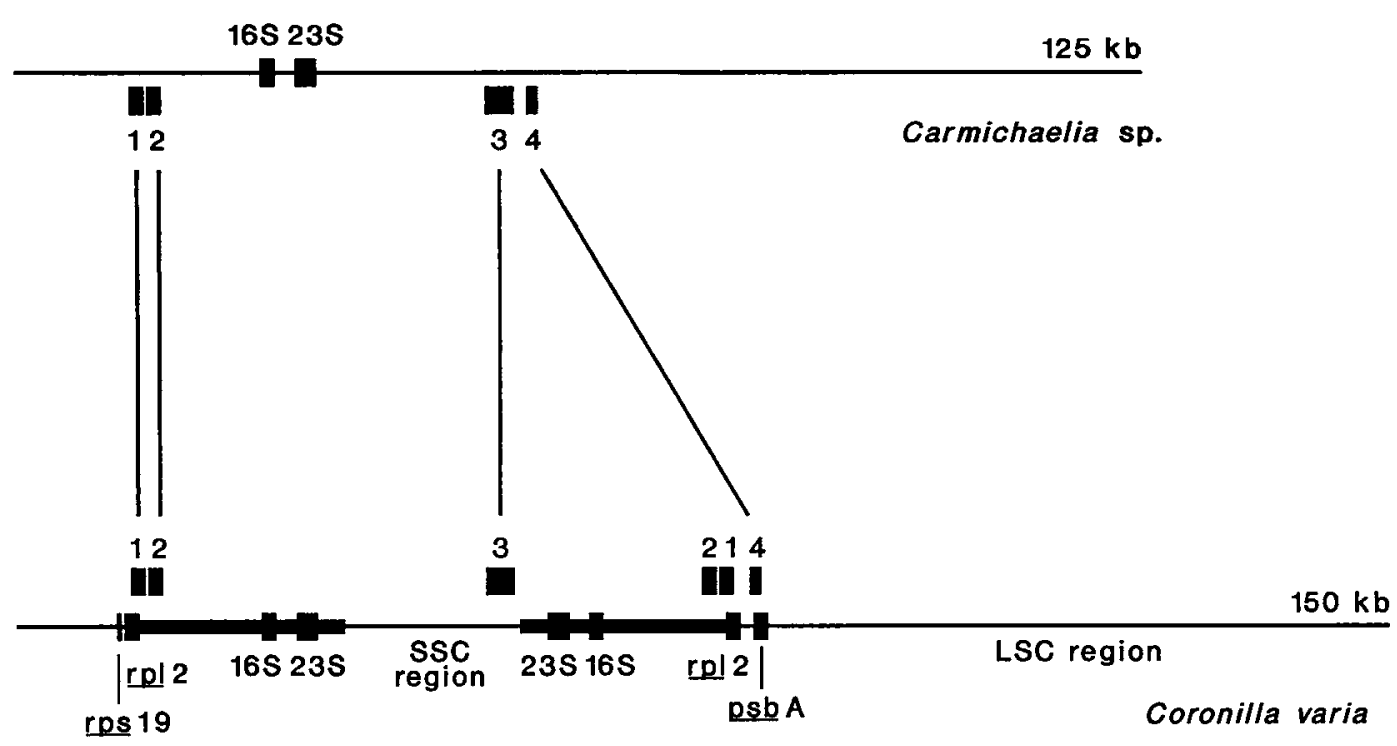

FIG. 1. Linearized representation of the chloroplast genome of Coronilla and Carmichaelia showing locations, relative to the inverted repeats, of genes discussed in the text and the four probe fragments (numbers $1,2,3$, and 4). The heavy lines connecting $r p l 2$ with $23 \mathrm{~S}$ indicate the region of the inverted repeated sequences. SSC = small single copy; $\mathrm{LSC}=$ large single copy.

tion; such mutations have been shown in other plant groups to be phylogenetically informative (Jansen and Palmer, 1987; Palmer et al., 1988a). Of particular interest here is the loss of a large (ca. 25-kb) inverted repeated sequence containing a duplicate set of ribosomal-RNA genes (Fig. 1). This loss is remarkable in that this repeat is an evolutionarily conserved feature of land-plant chloroplast DNA and is known to be absent otherwise only from certain conifers (Strauss et al., 1988). Structurally conserved features of the chloroplast-DNA inverted repeat, such as its size and position (dividing the genome into small and large single-copy regions of approximately $20 \mathrm{~kb}$ and $80 \mathrm{~kb}$, respectively), location relative to such flanking genes as $p s b A$, and ribosomal-RNAgene transcriptional orientation (toward the small single-copy region), suggest that the inverted repeat was present in the common ancestor of land plants (Palmer, 1985). Palmer et al. (1987), from a limited sampling of legumes, hypothesized that the loss of the chloroplast-DNA inverted repeat in Leguminosae occurred but once during the evolution of the subfamily Papilionoideae. The survey presented here attempts to as- sess the taxonomic distribution of the loss of the inverted repeat in the Leguminosae and its evolutionary significance.

\section{Materials aNd Methods}

Ninety-five species of Papilionoideae, representing 77 genera and 25 of the 31 tribes in this subfamily, have been surveyed for the loss of the inverted repeat (Table 1; voucher specimen information is available upon request from $M$. Lavin). In addition, 12 species from the subfamilies Caesalpinioideae and Mimosoideae were tested.

Techniques. - A fraction enriched in chloroplast-DNA sequences was obtained from most species by isolating a chloroplast pellet in a high-salt buffer (Bookjans et al., 1984 ) at a ratio of approximately $30 \mathrm{~g}$ of leaf material to $500 \mathrm{ml}$ of buffer. DNA was then isolated from the chloroplast pellet by adding an equal volume of the CTAB isolation buffer of Doyle and Doyle (1987) to the pellet and incubating at $60^{\circ} \mathrm{C}$ for onehalf hour. Subsequent chloroform/isoamylalcohol extraction, centrifugation, and alcohol precipitation followed Doyle and Doyle (1987). This method was especially useful for obtaining DNA from species with 
resinous leaves or mucilaginous extracts (e.g., those in the tribes Aeschynomeneae and Amorpheae). When leaf tissue was limited, total DNA was extracted by the CTAB method of Doyle and Doyle (1987).

DNAs were subjected to restriction-endonuclease digestions and electrophoresis in $0.7 \%$ agarose gels and transferred to MSI (Fisher) or Zetabind (Cuno) nylon membranes. Membrane-bound DNA fragments were hybridized serially with each of the clones described below that had been labeled with ${ }^{32} \mathrm{P}$ by nick-translation. Electrophoresis, transfer, hybridization, and autoradiography were performed as described in Doyle and Beachy (1985), except that nylon filters were used in place of nitrocellulose and Dextran sulfate was omitted from the hybridization solution.

DNA of all species listed in Table 1 was digested with at least two of the following restriction enzymes: $H$ ind III, Pst I, Pvu II, $S a c$ I, Sal I, Xba I, and Xho I. Two or more single digests of a given DNA of a single species were run side-by-side to maximize reproducibility of the hybridization assays that were used to diagnose the presence or absence of the repeat. Additionally, a single digest of the DNA of a species was run sideby-side with other species in the same tribe in order to assess more readily whether the repeat was consistently present or absent in a given tribe.

Strategy. - Two sets of small cloned probes were used to diagnose the presence or absence of the inverted repeat. The first set included cloned restriction fragments from Nicotiana tabacum (Fig. 1: probes 1 and 2) that were used to test for the presence of the chloroplast-DNA inverted repeat. These two probes (coordinates 88778-87745 for probe 1 [a $1.0-\mathrm{kb}$ Bam H I-Pst I fragment cloned into pTZ19R] and 90181-88778 for probe 2 [a 1.4-kb $B a m \mathrm{H}$ I fragment cloned into pTZ19R]; Shinozaki et al., 1986) are located near the large single-copy (LSC) margin of the inverted repeats and therefore normally have two regions of homology on the chloroplast chromosome. When chloroplast DNA is digested with a restriction enzyme having few recognition sites (e.g., Pst I or Pvu II), probes 1 and 2 will usually detect two filter-bound fragments if the inverted repeat is present and, furthermore, should often detect the same two fragments. When the inverted repeat is absent, probes 1 and 2 have only a single region of homology on the chromosome and should detect only a single fragment. Only if a restriction site is located within its region of homology will such a probe detect more than one fragment in a genome lacking the inverted repeat, in which case the adjacent probe will detect only one of these fragments.

Cloned restriction fragments in the second set contain sequences flanking that segment of the inverted repeat that is deleted in legumes (Palmer et al., 1987). These fragments were used in this survey to test for the absence of the inverted repeat (Fig. 1: probes 3 and 4). Probe 3 (a 3.1-kb $B a m H$ $\mathrm{I}-P s t \mathrm{I}$ fragment cloned in pUC 8 from $\mathrm{Vig}$ na radiata; Palmer et al., 1987) is at the margin of the small single-copy (SSC) region and probe 4 (a 1.2-kb Pst I-EcoR I fragment cloned into pUC 8 and containing the $3^{\prime}$ end of $p s b A$ from Pisum sativum; Oishi et al., 1984) is at the margin of the LSC region flanking the end of the inverted repeat segment. Each therefore has only a single region of homology on a chloroplast chromosome. These regions are normally separated by approximately $25 \mathrm{~kb}$ but are known to be adjacent in species with chloroplast DNA lacking an inverted repeat. Using a restriction enzyme with many recognition sites (e.g., Hind III or $X b a$ I), these two probes should generally detect the same filter-bound fragment of a DNA lacking the inverted repeat but should detect two different fragments of a genome with an inverted repeat.

We emphasize that it is the structural conservation of the inverted repeated sequence in the chloroplast genome of land plants that allows us to diagnose readily its presence or absence by the simple hybridization assays described above. The use of probes homologous with the end points of the inverted repeat is possible because it is precisely these end points that are evolutionarily conserved (Palmer, 1985). For example, the LSC region contains $p s b A$ at one end and rps19 at the other end in diverse species of monocots and dicots (Palmer, 1985). In addition, $r p l 2$ is located at the LSC margin of each repeat in nearly all an- 
giosperms (Fig. 1). Consequently, the use of probes containing such sequences should provide reliable results for diverse groups of angiosperms, let alone members of Leguminosae.

\section{RESULTS}

A total of 107 legume species have been examined for the presence/absence of the large inverted repeat in the chloroplast genome. The results of the survey are summarized in Table 1 , and a complete list of fragments detected by probes $1,2,3$, and 4 for each enzyme and species is available from M. Lavin upon request. In all 12 species of Caesalpinioideae and Mimosoideae surveyed, the inverted repeat was present. Of the 95 species of Papilionoideae so far examined, 70 species have the chloroplastDNA inverted repeat. Only Wisteria of the tribe Millettieae and all 24 species examined in the tribes Galegeae, Carmichaelieae, Hedysareae, Vicieae, Cicereae, and Trifolieae had a fragment phenotype consistent with the absence of the inverted repeat. The presence or absence of the repeat was consistent within each genus and, except for the tribe Millettieae, consistent within each tribe (Table 1).

Probes 1 and 2 (containing the LSC margin of the inverted repeat) provided a test for the presence of the inverted repeat. They both hybridized to two filter-bound fragments in DNA digests of most species, including members of three genera (Glycine, Lupinus, and Phaseolus) known to possess a chloroplast chromosome with an inverted repeat (Palmer et al., 1987). Moreover, these two adjacent probes nearly always detected the same two fragments, thus ruling out the possibility that the two fragments detected with one probe were caused by a restriction site within the area of probe homology. We consider this to be strong evidence for the presence of the chloroplast-DNA inverted repeat (Fig. 2A, B). This fragment phenotype was not observed from the DNA digests of species from the tribes Galegeae, Carmichaelieae, Hedysareae, Cicereae, Trifolieae, and Vicieae or from Wisteria; rather, the same single band was detected by these adjacent probes in each DNA (Fig. 2C, D). Among these species were several with a chloroplast chromosome already known to lack the inverted repeat (e.g., Cicer, Wisteria, Medicago, Trifolium, and Pisum; Palmer et al., 1987).

Probes 3 and 4 (located in the single-copy regions immediately flanking the inverted repeat that is putatively lost in the Papilionoideae; Palmer et al., 1987) provided a test for the absence of the inverted repeat. These two probes always detected the same filterbound DNA fragment in species of the tribes Galegeae, Carmichaelieae, Hedysareae, Cicereae, Trifolieae, and Vicieae, as well as in Wisteria (Fig. 3A, B). They hybridized to different fragments of the DNA digests of species from other tribes (Fig. 3C, D).

The fact that probes 3 and 4 hybridized to the same DNA fragment in individual DNA digests of Wisteria and members of the six tribes listed above suggests that, of the four possible inverted repeat "segment orientations" (Palmer et al., 1987), the one flanked by $p s b A$ and the sequence homologous with the $3.1-\mathrm{kb}$ mung-bean fragment (i.e., probe 3 ) is the one that was lost. Probes 3 and 4 would only rarely hybridize to the same fragment if the inverted repeat that was lost had other flanking-sequence orientations.

This hybridization assay using probes homologous with the end points of the inverted repeated sequences has an advantage in allowing a simultaneous test for the presence (probes 1 and 2) and absence (probes 3 and 4) of the repeat. These two independent assays always gave the same answers in the species of Leguminosae we surveyed. Furthermore, identical results were nearly always obtained using multiple enzymes for a given DNA. Species with chloroplast DNA that we interpret as lacking the inverted repeat would occasionally show hybridization of probes 3 and 4 to different fragments in one of the several enzyme digests (presumably because of a restriction site between the regions of homology of these two probes). Likewise, species with chloroplast DNA that we interpret as having the inverted repeat would show, in one of several enzyme digests, hybridization of probes 3 and 4 to seemingly the same fragment (presumably two different fragments with equal mobility).

Additional confirmation of the presence/ absence of the inverted repeat is found in 
TABLE 1. Species of Leguminosae surveyed for the loss of the chloroplast-DNA inverted repeat. Asterisks indicate absence of the inverted repeat. Vigna radiata and Vicia faba are reported here from Palmer et al. (1987) and Koller and Delius (1980), respectively. Voucher specimen information and details of fragment sizes detected by probes for each species are available upon request from the first author.

\begin{tabular}{|c|c|c|}
\hline Subfamily & Tribe & Species \\
\hline \multirow[t]{17}{*}{ Papilionideae } & Abreae & Abrus precatorius \\
\hline & Aeschynomeneae & $\begin{array}{l}\text { Aeschynomene indica } \\
\text { A. pfundii } \\
\text { A. rudis } \\
\text { A. virginica } \\
\text { Arachis hypogea } \\
\text { Diphysa robinioides }\end{array}$ \\
\hline & Amorpheae & $\begin{array}{l}\text { Amorpha fruticosa } \\
\text { Dalea candida } \\
\text { D. purpurea } \\
\text { Eysenhardtia texana } \\
\text { Psorothamnus kingii }\end{array}$ \\
\hline & Bossiaeeae & Goodia latifolia \\
\hline & Brongniartieae & Brongniartia pacifica \\
\hline & Carmichaelieae & Carmichaelia sp.* \\
\hline & Cicereae & Cicer sp.* \\
\hline & Coronilleae & Coronilla varia \\
\hline & Crotalarieae & Crotalaria mucronata \\
\hline & Dalbergieae & $\begin{array}{l}\text { Pterocarpus indica } \\
\text { Tipuana tipu }\end{array}$ \\
\hline & Desmodieae & $\begin{array}{l}\text { Desmodium grandiflorum } \\
\text { Lespedeza sp. }\end{array}$ \\
\hline & Galegeae & $\begin{array}{l}\text { Astragalus aboriginum } \\
\text { A. adsurgens* } \\
\text { A. alpinu* } \\
\text { A. cicer* } \\
\text { A. pectinatus* } \\
\text { Caragana arborescens* } \\
\text { Clianthus formosus* }^{*} \\
\text { Glycyrrhiza glabra* } \\
\text { Oxytropis deflexa* } \\
\text { O. campestris* } \\
\text { O. multiceps } \\
\text { O. splendens } \\
\text { Sphaerophysa salsula* }\end{array}$ \\
\hline & Genisteae & $\begin{array}{l}\text { Genista canariensis } \\
\text { Laburnum anagyroides } \\
\text { Lupinus polyphyllus }\end{array}$ \\
\hline & Hedysareae & $\begin{array}{l}\text { Hedysarum alpinum } \\
\text { Onobrychis sativa* }\end{array}$ \\
\hline & Indigofereae & $\begin{array}{l}\text { Cyamopsis tetragonoloba } \\
\text { Indigofera miniata }\end{array}$ \\
\hline & Loteae & $\begin{array}{l}\text { Lotus australis } \\
\text { L. corniculatus } \\
\text { L. strigosus }\end{array}$ \\
\hline & Millettieae & $\begin{array}{l}\text { Dalbergiella nyasae } \\
\text { Derris elliptica } \\
\text { Kunstleria blackii } \\
\text { Lonchocarpus eriocarinalis } \\
\text { Millettia dura } \\
\text { Piscidia piscipula } \\
\text { Tephrosia cinerea } \\
\text { T. heckmanniana } \\
\text { T. rhodesica } \\
\text { T. villosa }\end{array}$ \\
\hline
\end{tabular}


TABle 1. Continued.

\begin{tabular}{|c|c|c|}
\hline Subfamily & Tribe & Species \\
\hline & & $\begin{array}{l}\text { Wisteria floribunda* } \\
\text { Xeroderris stuhlmanii }\end{array}$ \\
\hline & Mirbelieae & Chorizema chordata \\
\hline & Phaseoleae & $\begin{array}{l}\text { Cajanus cajan } \\
\text { Canavalia maritima } \\
\text { Centrosema virginiana } \\
\text { Erythrina herbacea } \\
\text { Glycine max } \\
\text { Kennedia rubicunda } \\
\text { Mucuna sp. } \\
\text { Phaseolus vulgaris } \\
\text { Sphenostylis sp. } \\
\text { Vigna radiata }\end{array}$ \\
\hline & Robinieae & $\begin{array}{l}\text { Coursetia heterantha } \\
\text { C. hypoleuca } \\
\text { Daubentonia tripettii } \\
\text { Glircidia sepium } \\
\text { Glottidium vesicarium } \\
\text { Hebestigma cubense } \\
\text { Olneya tesota } \\
\text { Robinia pseudoacacia } \\
\text { Sesbania sesban } \\
\text { Sphinctospermum constrictum } \\
\text { Sabinea carinalis }\end{array}$ \\
\hline & Sophoreae & $\begin{array}{l}\text { Bolusanthus speciosus } \\
\text { Calpurnea aurea } \\
\text { Myrospermum sousanum } \\
\text { Ormosia columbiana } \\
\text { Sophora affinis } \\
\text { S. secundiflora }\end{array}$ \\
\hline & Swartzieae & Swartzia sp. \\
\hline & Thermopsideae & $\begin{array}{l}\text { Baptisia leucophaea } \\
\text { Thermopsis divaricarpa }\end{array}$ \\
\hline & Trifolieae & $\begin{array}{l}\text { Medicago sativa* } \\
\text { Melilotus alba* } \\
\text { Trifolium pratense* }\end{array}$ \\
\hline & Vicieae & $\begin{array}{l}\text { Lathyrus sp.* } \\
\text { Lens esculenta } \\
\text { Pisum sativum* } \\
\text { Vicia faba* }\end{array}$ \\
\hline Mimosoideae & & $\begin{array}{l}\text { Acacia sp. } \\
\text { Calliandra emarginata } \\
\text { Desmanthus subulatus } \\
\text { D. virgatus } \\
\text { Dichrostachys cinerea } \\
\text { Enterolobium cyclocarpum } \\
\text { Leucaena } \text { sp. } \\
\text { Neptunia pubescens }\end{array}$ \\
\hline Caesalpinioideae & & $\begin{array}{l}\text { Bauhinia sp. } \\
\text { Brownea sp. } \\
\text { Caesalpinia platyloba } \\
\text { Gleditsia triacanthos }\end{array}$ \\
\hline
\end{tabular}

published reports on chloroplast-DNA ribosomal-gene arrangements for Cicereae and Phaseoleae (Cicer, Glycine, and Vigna; Chu and Tewari, 1982) and for Vicieae (Vi- cia; Koller and Delius, 1980). Confirming evidence is also found in chloroplast-DNA restriction maps of Genisteae (Lupinus), Millettieae (Wisteria), Phaseoleae (Glycine, 


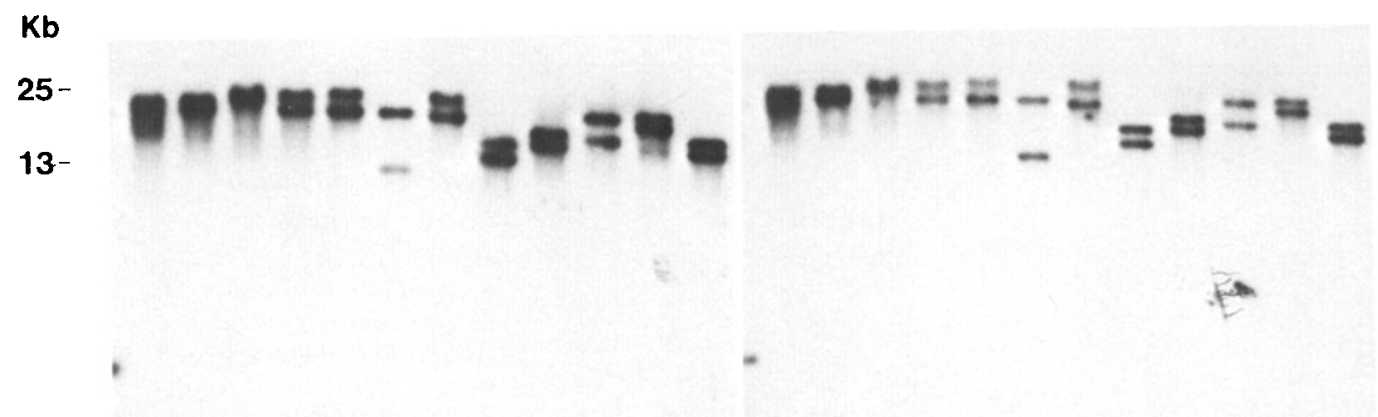

$\begin{array}{lll}\text { probe } 1 & \text { 2A probe 2 }\end{array}$

23-

16 -
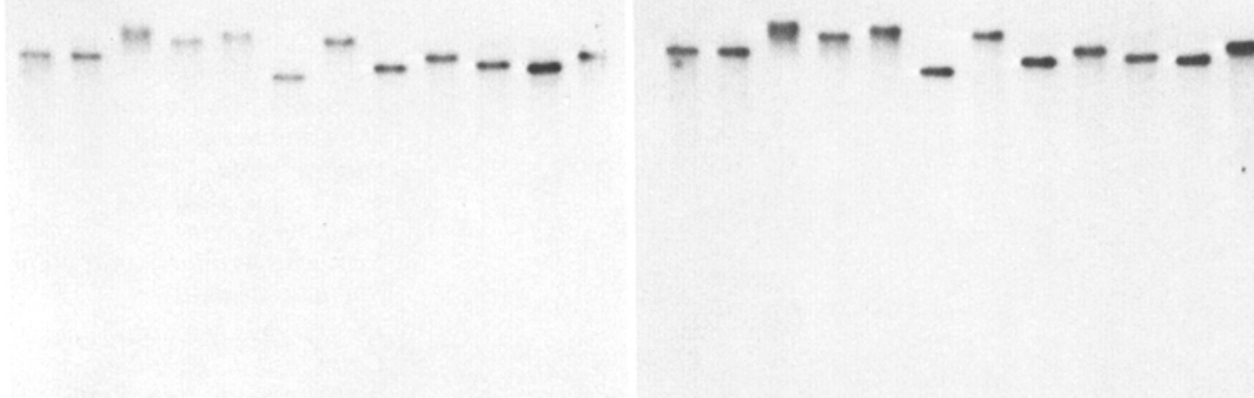

probe 1

2C probe 2

FIG. 2. Autoradiographs of filter-bound DNA fragments of A, B) Coronilla varia and C, D) Carmichaelia sp. hybridized with probes 1 and 2 . The lanes represent, from left to right, restriction-enzyme digestions of $S a c$ I, Sac I-Sal I, Sal I, Sal I-Pst I, Pst I, Pst I-Pvu II, Pvu II, Pvu II-Xho I, Xho I, Sac I-Pst I, Sac I-Pvu II, Sac I-Xho I.

Phaseolus, and Vigna), Trifolieae (Medicago and Trifolium), and Vicieae (Lathyrus, Lens, Pisum, and Vicia) (Palmer et al., 1987, $1988 b$ ) and, more recently in chloroplastDNA restriction maps of Carmichaelieae (Carmichaelia), Coronilleae (Coronilla), Galegeae (Astragalus and Clianthus), Hedysareae (Onobrychis), Loteae (Lotus), Millettieae (Piscidia and Tephrosia), and Robinieae (Coursetia, Gliricidia, Hebestigma, Sesbania, and Sphinctospermum) (Lavin and Doyle, unpubl.). Our interpretations from the experiments reported here using small probes from the ends of the inverted repeat and single-copy regions are in complete agreement with these data.

\section{Discussion}

Polhill's (1981a p. 199) hypothesis of tribal relationships in Papilionoideae is the only comprehensive scheme to date. The taxonomic distribution of the inverted-repeat mutation occurs almost exclusively within one of Polhill's lineages which includes temperate herbaceous tribes that accumulate canavanine (Galegeae, Carmichaelieae, Hedysareae, Vicieae, Cicereae, and Trifolieae). It is among this group of legumes that this new chloroplast-DNA character shows promise in testing existing taxonomic hypotheses.

We emphasize that the evolutionary polarity of this mutation is absolutely unambiguous; all species examined from each of more than 60 angiosperm families (Palmer, 1985, unpubl.), as well as Caesalpinioideae and Mimosoideae (Table 1), have a chloroplast chromosome with an inverted repeat. Loss of the inverted repeat has occurred in six tribes (Galegeae, Hedysareae, 


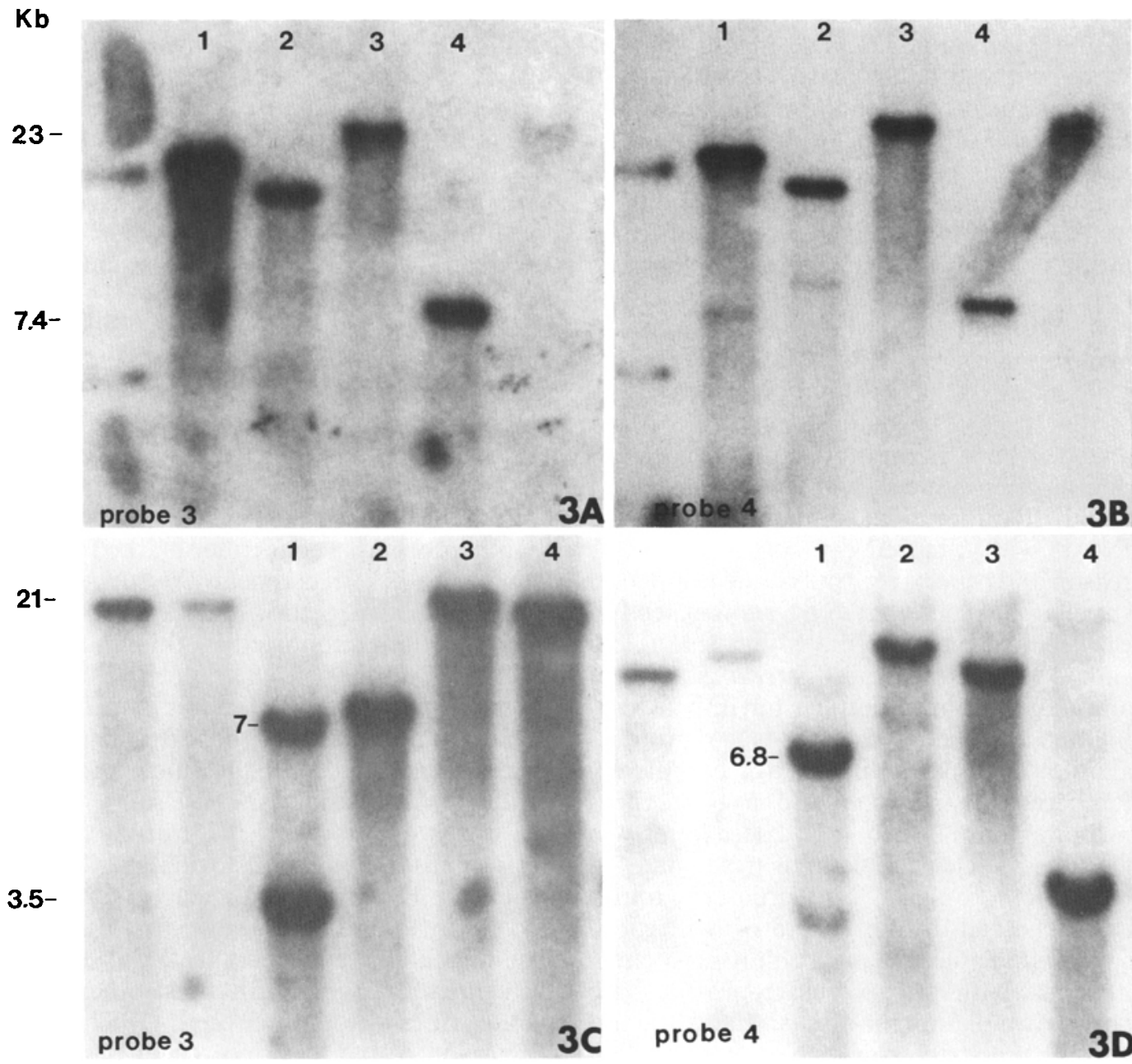

FIG. 3. Autoradiographs of filter-bound DNA fragments of A, B) Cicer sp. and C, D) Canavalia maritima, hybridized with probes 3 and 4. Lanes $1-4$ represent, respectively, restriction-enzyme digestions of Hind III, $P v u$ II, Sac I, and Xba I.

Carmichaelieae, Vicieae, Cicereae, and Trifolieae) and also in the genus Wisteria of the tribe Millettieae. Given the general congruence of the distribution of this chloroplast-DNA structural mutation with the classification of Papilionoideae, as well as the consistency of its presence/absence within a genus, we substantiate the hypothesis of Palmer et al. (1987) that the loss of the chloroplast-DNA inverted repeat occurred only once among legumes and that it marks a monophyletic subgroup of Papilionoideae.

The recognition of this monophyletic group of tribes (Galegeae, Carmichaelieae,
Hedysareae, Trifolieae, Cicereae, and Vicieae) should be of little surprise to legume systematists. These tribes share a predominantly herbaceous growth habit, centers of diversity in temperate regions of the Old World, and marker characters (such as epulvinate leaves and stipules adnate to the petiole) (Polhill, 1981a). These chloroplastDNA data support Polhill's (1981d) placement of Glycyrrhiza within this group, from which it has been excluded because of its pulvinate leaves with stipules free from the petiole.

Other findings revealed by these chloroplast-DNA data are completely unexpected 
and provide new insights into the evolution of the Papilionoideae. The inconsistencies between these chloroplast-DNA data and the classification of the Papilionoideae are the absence of the repeat in the genus Wisteria, and its presence in the tribes Loteae and Coronilleae. It is the taxonomic distribution of this inverted repeat structural mutation that, for the first time, clearly suggests a relationship of temperate tribes with tropical ones and yields new insight into the evolutionary change of certain morphological features, such as the pseudoraceme.

Wisteria. - The genus Wisteria possesses a woody liana habit and seedlings with hypogeal germination, two characteristics of woody Papilionoideae inhabiting tropical forests with a closed canopy. It is for this reason and others (e.g., pulvinate leaves and stipellate leaflets) that Wisteria is placed in the tropical woody tribe Millettieae (Geesink, 1984). However, Wisteria is atypical among genera of Millettieae not only in having this unusual chloroplast-DNA structural mutation, but also in having a completely temperate distribution and a base chromosome number of $x=8$. These latter two features are characteristic of tribes marked by the chloroplast-DNA structural mutation. The eight other genera of Millettieae surveyed (Table 1) have a chloroplast chromosome with an inverted repeat, a base chromosome number of $x=11$ and 12 , and a tropical distribution (these latter two features are known from nearly all genera of Millettieae). Wisteria also is anomalous in Millettieae in lacking a pseudoracemose inflorescence, a trait distinctive of most other Millettieae and closely related tribes (Tucker, 1987).

However, the actual disposition of Wisteria remains problematic. A cladistic analysis of advanced woody Papilionoideae (i.e., those that accumulate nonprotein amino acids; Lavin, unpubl.) suggests that Wisteria did not attain features typical of Millettieae (woody habit, pulvinate leaves, hypogeal seedling germination, reduced hypanthium, and intrastaminal nectary) secondarily from herbaceous ancestors lacking these traits; therefore, it does not seem to be readily accommodated into other temperate tribes. Although such features weigh heavily in placing Wisteria in Millettieae, they are not anomalous in temperate groups. For example, the tribe Carmichaelieae is entirely woody (the extinct Streblorrhiza of this tribe is described as having an overall appearance of genera in Millettieae, as well as "Wisteria-like" flowers in Polhill [1981b]), as are Caragana and members of other genera in the tribe Galegeae. The tribes Vicieae and Cicereae are characterized by seedlings with hypogeal germination, and Glycyrrhiza of the tribe Galegeae has pulvinate leaves. Thus, it is possible that further study will show that Wisteria can be accommodated among the temperate tribes. At the least, Wisteria should be regarded as an unspecialized member of the woody papilionoid lineage that gave rise to the temperate, predominantly herbaceous tribes marked by the loss of the inverted repeat. As such, Geesink's (1984) suggestion that Millettieae is paraphyletic is supported by this finding.

The possibility of a parallel loss of the inverted repeat in Wisteria is diminished because probes 3 and 4 , those that flank the inverted repeat, detect the same fragment in all enzyme digestions. These same results are observed in the hybridization assays performed on species of Galegeae, Carmichaelieae, Hedysareae, Vicieae, Trifolieae, and Cicereae, and this suggests that Wisteria lost the same inverted repeat, flanked by the same sequences, as did these other temperate tribes (see Palmer et al. [1987] for a discussion of the inverted repeat flankingsequence orientations).

Many genera presently placed in Millettieae, Galegeae, and other related tribes were once included in a large heterogeneous tribe Galegeae (sensu Bentham, 1865). However, subsequent anatomical (Dormer, 1946) and chromosomal (Turner and Fearing, 1959; Goldblatt, 1981) evidence revealed a distinction between the temperate representatives of this tribe (with a predominantly herbaceous growth habit and a base chromosome number of $x=8$ ) and those more tropical in distribution (with a predominantly woody habit and a base chromosome number of $x=11$ ). The loss of the chloroplast-DNA inverted repeat further distinguishes these temperate genera from putative close relatives in tropical regions.

Other members of the Millettieae yet to be examined may also have this chloro- 
plast-DNA structural mutation. For example, Millettia japonica is distinctive in having a base chromosome number of $x=$ 8 and a temperate distribution, and this species has been postulated to be closely related to Wisteria (Geesink, 1984). The genus Sarcodum is also considered by Geesink (1984) to be closely related to Wisteria and, therefore, Sarcodum may have a chloroplast chromosome lacking an inverted repeat. Finally, the New World species of Wisteria have been generically segregated from the Old World species (Stritch, 1984), but it is unknown whether the mutation is consistently present in both groups. Although DNAs of Millettia japonica, species of Sarcodum, and New World Wisteria were not available for this study, the final assessment of the distribution of the loss of the chloroplast-DNA inverted repeat in Millettieae will be significant in revealing the closest tropical relatives of the temperate, predominantly herbaceous tribes.

Loteae and Coronilleae. - The tribes Loteae and Coronilleae traditionally have been regarded as derived elements of the temperate tribes here shown to be characterized by the chloroplast-DNA mutation. Evidence used to group these two tribes with other temperate tribes comes largely from their herbaceous growth habit and associated characters (e.g., a closed vascular system and stipules adnate to the petiole; Polhill, 1981a) and a center of diversity in temperate regions of the Old World. Loteae and Coronilleae together share many presumably derived features, such as specialized pollen (Polhill, 1981c; Ferguson and Skvarla, 1981), seedlings with exceptionally long and narrow cotyledons, and a suppressed plumule (Duke and Polhill, 1981), and a base chromosome number of $x=7$. The number of postulated specializations found in these two tribes has been used as evidence for their derived condition within the temperate lineage.

However, some of these specializations may not be of unique derivation but, rather, the result of recent common ancestry with tropical tribes such as Phaseoleae and Millettieae. In particular, characters of the pollen are suggestive of this relationship. Loteae and Coronilleae have a specialized pollen-wall morphology, which consists of a very reduced to absent foot layer, reduced columellae, and a thick exine. This morphology is commonly found in genera of the Phaseoleae and Millettieae (Polhill, pers. comm.; see Ferguson and Skvarla, 1981), as well as in Coronilleae and Loteae, but it is rarely found elsewhere in the family.

Root-nodule morphology, which Corby (1981) suggests is taxonomically useful at the tribal level, provides additional evidence that the Loteae and Coronilleae are related to tropical tribes. Loteae and Coronilleae possess the determinate nodule, as do Phaseoleae, while other temperate tribes surveyed that have the chloroplast-DNA structural mutation (i.e., Galegeae, Hedysareae, Vicieae, Cicereae, and Trifolieae) have an indeterminate root nodule (Sprent, 1981). Corby (1981) suggests that the indeterminate nodule (his Astragaloid type) is the ancestral type and that determinate root nodules are more specialized. That this derived trait is shared by Loteae, Coronilleae, and tropical tribes such as Phaseoleae is strong evidence of relationship. Sprent (1981) expressed difficulty in speculating on the possible advantages of determinate nodules (as found in the Loteae and Coronilleae) in the temperate line of evolution in which the indeterminate nodule was predominant (as in the Galegeae and closely related tribes). A new hypothesis formulated from these chloroplast-DNA data suggests that the Loteae and Coronilleae represent an independent temperate lineage that inherited the determinate type of root nodule from tropical ancestors similar to Phaseoleae.

Inflorescence morphology may provide additional evidence for the relationship of the Loteae and Coronilleae to tribes such as Phaseoleae and Millettieae. The umbellate inflorescence found in nearly all species of Loteae and Coronilleae is readily distinct from that found in supposedly related temperate tribes; multiple flowers emanate from a single node and reach anthesis synchronously. This condition is very similar, and perhaps homologous, to the pseudoracemose condition found in the tribes Abreae, Desmodieae, Millettieae, Phaseoleae, and Psoraleeae. Tucker (1987) suggests that these five predominantly tropical tribes represent a monophyletic group marked by this inflo- 
rescence type. Perhaps Loteae and Coronilleae can be added to this group if their umbellate inflorescences are found to be homologous with the pseudoraceme, as characterized by Tucker (1987).

Finally, two other characters are in need of close study, as they may also reveal the relationships of Loteae and Coronilleae. Ingham (1981) points out that benzofurans are known in Papilionoideae only from a few genera in the Phaseoleae and Loteae. Additionally, staminal filaments that are distally expanded have been used to characterize the Loteae and Coronilleae; however, this attribute is also found in some genera of the Phaseoleae.

\section{Conclusion}

The deletion of the chloroplast-DNA inverted repeat provides a means of testing the traditional evidence used in reconstructing the phylogeny of Papilionoideae. The discovery of this mutation has been remarkable in that, with the exception of Tucker's (1987) work on inflorescence morphology, little new information has become available in the last few years bearing on relationships at the tribal level in Papilionoideae. The recognition of a large monophyletic group comprising the tribes Galegeae, Carmichaelieae, Hedysareae, Vicieae, Cicereae, and Trifolieae should be of little surprise to botanists familiar with the subfamily. It will be of much more interest, however, to reassess the relationships of the tribes Loteae and Coronilleae, as well as to find the specific genera in the Millettieae that are the closest tropical relatives of the temperate tribes marked by this chloroplast-DNA structural mutation.

Palmer et al. (1988b) have speculated as to why the chloroplast DNA of Leguminosae is so much more variable than that of most other land plants. Particularly, they asked whether the chloroplast DNA of legumes is such that it is predisposed to deletions and inversions or whether the loss of the inverted repeat has a destabilizing effect on the chloroplast chromosome. The evidence gathered in the present study addresses only the issue of the origin of this chloroplast-DNA mutation. Given that its distribution is generally congruent with the existing classification, it is likely that the loss of the inverted repeat was a single mutational event in Leguminosae and not of parallel origin in a family with inherently variable chloroplast chromosomes.

From its taxonomic distribution, this mutational event of the chloroplast genome occurred later than much of the evolution and diversification of the Papilionoideae. It occurred after the origin of canavanine synthesis (an important taxonomic marker in Papilionoideae that occurs in all the tribes with the chloroplast-DNA mutation) but predates the evolution of the predominantly herbaceous growth habit (the mutation is found not only in the woody liana Wisteria, but also in the woody tribe Carmichaelieae and in woody Galegeae such as Caragana). Because no tropical representatives have been found to have lost the inverted repeat, the mutation very likely originated in a papilionoid group already established in a paleotemperate habitat. If we extrapolate from our sample, this group of temperate tribes marked by a chloroplast chromosome lacking the inverted repeat comprises $c a$. 3,800 species and $\mathbf{4 5}$ genera and includes the largest genus of flowering plants, Astragalus, with approximately 2,000 species. Many cultivated plants are also found in this group, such as licorice root, peas, lentils, chickpeas, alfalfa, and clover, as well as economically important weeds such as the locoweeds. Whatever the effect of this mutation on the structural stability of the chloroplast genome, it apparently does not have a deleterious effect on the ability of this lineage to evolve numerous species that predominate in many vegetation types.

These chloroplast-DNA data suggest a new taxonomic hypothesis for a large group of temperate legume tribes. They reveal specific characters in need of investigation that may prove useful in reformulating the current classification of temperate Papilionoideae. Not only should taxonomic relationships be better resolved, but our knowledge of morphological evolution in this group should increase (e.g., by possibly revealing unrecognized modifications of the pseudoraceme, such as that postulated for the Loteae and Coronilleae). The distribution of the loss of the chloroplast-DNA inverted repeat and other structural mutations currently under study should provide many new 
insights into the evolution of the Leguminosae.

\section{ACKNOWLEDGMENTS}

We thank the following individuals and institutions for leaf or seed material used in this study: A. Alvarez, A. Delgado, H. Hedrick, C. Hughes, G. Lewis, M. Luckow, F. Gregoire, P. Manos, G. Nesom, B. Ozbirn, V. Phelps, A. M. Powell, R. Riggins, M. Sousa, J. Vukelich, N. Weeden, A. Whittemore, Adelaide Botanical Garden, Hong Kong Botanical Garden, Kew Royal Botanical Gardens, and Zimbabwe National Botanic Gardens. We thank A. Bruneau and J. Doyle for technical assistance and R. C. Barneby and R. M. Polhill for helpful comments. Financial support for this study was provided by grants from the National Science Foundation (BSR-8700164 to M.L.; BSR-8516630 and BSR-8805630 to J.J.D.; BSR-8717600 to J.D.P.) and from the United States Department of Agriculture (Hatch NYC-187405 to J.J.D.).

\section{Literature Cited}

Bentham, G. 1865. Papilionaceae, pp. 465-562. In G. Bentham and J. D. Hooker (eds.), Genera Plantarum, Vol. 1. Reeve \& Co., London, U.K.

Bookjans, G., B. M. Stummann, and K. W. HenNINGSEN. 1984. Preparation of chloroplast DNA from pea plastids isolated in a medium of high ionic strength. Anal. Biochem. 141:244-247.

ChU, N. M., AND K. K. Tewari. 1982. Arrangement of the ribosomal RNA genes in chloroplast DNA of Leguminosae. Molec. Gen. Genet. 186:23-32.

CORBY, H. D. L. 1981. The systematic value of leguminous root nodules, pp. 657-670. In R. M. Polhill and P. H. Raven (eds.), Advances in Legume Systematics, Part 2. Royal Botanic Gardens, Kew, U.K.

CronQuist, A. 1981. An Integrated System of Classification of Flowering Plants. Columbia Univ. Press, N.Y.

DORMER, K. J. 1946. Vegetative morphology as a guide to the classification of Papilionatae. New Phytol. 45:145-161.

DOYLE, J. J., AND R. N. BEACHY. 1985. Ribosomal gene variation in soybean (Glycine) and its relatives. Theoret. Appl. Genet. 70:369-376.

DOYLE, J. J., AND J. L. DOYLE. 1987. A rapid DNA isolation procedure for small quantities of fresh leaf tissue. Phytochem. Bull. 19:11-15.

DuKe, J. A., AND R. M. Polhill. 1981. Seedlings of the Leguminosae, pp. 941-950. In R. M. Polhill and P. H. Raven (eds.), Advances in Legume Systematics, Part 2. Royal Botanic Gardens, Kew, U.K.

Ferguson, I. K., AND J. J. SKVARLA. 1981. The pollen morphology of the subfamily Papilionoideae (Leguminosae), pp. 859-898. In R. M. Polhill and P.
H. Raven (eds.), Advances in Legume Systematics, Part 2. Royal Botanic Gardens, Kew, U.K.

GeEsINK, R. 1984. Scala Millettiearum. Leiden Botanical Series, Vol. 8. Brell/Leiden Univ. Press, Leiden, Neth.

GoldBLATT, P. 1981. Cytology and the phylogeny of Leguminosae, pp. 427-464. In R. M. Polhill and P. H. Raven (eds.), Advances in Legume Systematics, Part 2. Royal Botanic Gardens, Kew, U.K.

InGHaM, J. L. 1981. Phytoalexin induction and its taxonomic significance in the Leguminosae (subfamily Papilionoideae), pp. 599-626. In R. M. Polhill and P. H. Raven (eds.), Advances in Legume Systematics, Part 2. Royal Botanic Gardens, Kew, U.K.

JANSEN, R. K., AND J. D. PAlmer. 1987. A chloroplast DNA inversion marks an ancient evolutionary split in the sunflower family (Asteraceae). Proc. Nat. Acad. Sci. USA 84:5818-5822.

Koller, B., AND H. Delius. 1980. Vicia faba chloroplast DNA has only one set of ribosomal RNA genes as shown by partial denaturation mapping and R-loop analysis. Molec. Gen. Genet. 178:261269.

OISHI, K. K., D. R. Shapiro, AND K. K. TeWari. 1984. Sequence organization of a pea chloroplast DNA gene coding for a 34,500-dalton protein. Molec. Cell. Biol. 4:2556-2563.

PALMER, J. D. 1985. Comparative organization of chloroplast genomes. Ann. Rev. Genet. 19:325-354.

Palmer, J. D., R. K. Jansen, H. J. Michaels, M. W. Chase, AND J. R. Manhart. 1988a. Chloroplast DNA variation and plant phylogeny. Ann. Missouri Bot. Gard. 75:1180-1206.

Palmer, J. D., B. Osorio, J. Aldrich, ANd W. F. THOMPSON. 1987. Chloroplast DNA evolution among legumes: Loss of a large inverted repeat occurred prior to other sequence rearrangements. Curr. Genet. 11:275-286.

Palmer, J. D., B. Osorio, and W. F. Thompson. $1988 b$. Evolutionary significance of inversions in legume chloroplast DNAs. Curr. Genet 14:65-74.

PolhILl, R. M. 1981a. Papilionoideae, pp. 191-208. In R. M. Polhill and P. H. Raven (eds.), Advances in Legume Systematics, Part 1. Royal Botanic Gardens, Kew, U.K.

- 1981b. Carmichaelieae, pp. 364-366. In R. M. Polhill and P. H. Raven (eds.), Advances in Legume Systematics, Part 1. Royal Botanic Gardens, Kew, U.K.

1981c. Loteae and Coronilleae, pp. 371-375. In R. M. Polhill and P. H. Raven (eds.), Advances in Legume Systematics, Part 1. Royal Botanic Gardens, Kew, U.K.

1981d. Galegeae, pp. 357-363. In R. M. Polhill and P. H. Raven (eds.), Advances in Legume Systematics, Part 1. Royal Botanic Gardens, Kew, U.K.

Polmill, R. M., AND P. H. Raven (eds.). 1981. Advances in Legume Systematics, Part 1. Royal Botanic Gardens, Kew, U.K.

Shinozaki, K., M. Ohme, M. Tanaka, T. Wakasugi, N. Hayashida, T. Matsubayashi, N. Zaita, J. Chunwongse, J. Obokata, K. Yamaguchi-Shinozaki, C. Ohto, K. Torazawa, B. Y. Meng, M. Sugita, H. Deno, T. Kamogashira, K. 

Yamada, J. Kusuda, F. Takaiwa, A. Kato, N.
Tohdoh, H. Shimada, and M. Sugiura. 1986. The complete nucleotide sequence of the tobacco chloroplast genome: Its gene organization and expression. EMBO J. 5:2043-2049.

SPRENT, J. I. 1981. Functional evolution in some papilionoid root nodules, pp. 671-676. In R. M. Polhill and P. H. Raven (eds.), Advances in Legume Systematics, Part 2. Royal Botanic Gardens, Kew, U.K.

Strauss, S. H., J. D. Palmer, G. T. Howe, and A. H. DOERKSEN. 1988. Chloroplast genomes of two conifers lack a large inverted repeat and are extensively rearranged. Proc. Nat. Acad. Sci. USA 85 : 3898-3902.
StiRTon, C. (ed.). 1987. Advances in Legume Systematics, Part 3. Royal Botanic Gardens, Kew, U.K.

StRITCH, L. R. 1984. Nomenclatural contributions to a revision of the genus Wisteria. Phytologia 56: 183-184.

TUCKER, S. C. 1987. Pseudoracemes in papilionoid legumes: Their nature, development, and variation. Bot. J. Linn. Soc. 95:181-206.

TURner, B. L., AND O. S. Fearing. 1959. Chromosome numbers in the Leguminosae II. African species including phyletic interpretations. Amer. J. Bot. 46:49-57.

Corresponding Editor: R. L. Honeycutt 